\title{
PRING KOENING" Di Kelurahan Bunulrejo Kecamatan Blimbing Kota Malang
}

\author{
Mochammad Rofieq ${ }^{1}$ \\ Roos Widjajani ${ }^{2}$ \\ Nanny Roedjinandari ${ }^{3}$
}

Jurusan Teknik Industri Universitas Merdeka Malang ${ }^{1}$

Jurusan Administrasi Bisnis Universitas Merdeka Malang ${ }^{2}$

Program Diploma Kepariwisataan Universitas Merdeka Malang ${ }^{3}$

mochammad.rofieq@unmer.ac.id

$1 *$

Akuntansi Bisnis dan

Manajemen (ABM),

Volume 7

Nomor 2

Halaman 27-8

Bulan Desember,

Tahun 2020

ISSN 2477-6432

E-ISSN 2721-141X

\section{Informasi Artikel}

Tanggal Masuk:

11 Nov 2020

Tanggal Revisi:

20 Nov 2020

Tanggal Diterima:

8 Des 2020

\section{Abstrak}

Salah satu wilayah di Kota Malang yang sebagian warganya adalah generasi muda yang berwirausaha di bidang kuliner adalah Kelurahan Bunulrejo Kecamatan Blimbing khususnya di RT.02 / RW.13. Para pelaku UKM yang ada di wilayah ini membentuk wadah untuk beraktifitas bersama dengan nama "Kampung Kuliner Pring Koening". Komunitas ini merupakan mitra dalam Program Unmer Membangun Desa dengan fokus mengintegrasikan pengelolaan UKM kuliner dengan pengembangan kawasan wisata serta pembinaan kemandirian dan kewirausahan bagi generasi muda di wilayah ini. Melalui program ini dihasilkan sinergi positif antara akademisi dan masyarakat dalam mengembangkan kawasan wisata kuliner, sehingga setiap konsumen yang berkunjung tidak hanya membeli makanan / minuman yang ditawarkan, namun juga dapat merasakan kenyamanan sambil berwisata dan mendapatkan image dari branding yang diberikan.

Kata Kunci : Kewirausahaan, Pemberdayaan, UKM, Wisata Kuliner.

\begin{abstract}
One of the areas in Malang City where some of its citizens are young people who are entrepreneurs in the culinary field is Bunulrejo Village, Blimbing District, especially in RT.02 / RW.13. The SMEs in this area form a forum for activities together with the name "Pring Koening Culinary Village". This community is a partner in the Unmer Building Village Program with a focus on integrating the management of culinary SMEs with the development of tourist areas as well as fostering independence and entrepreneurship for the younger generation in this region. Through this program, a positive synergy has been generated between academics and the community in developing culinary tourism areas, so that every visiting consumer not only buys the food / drink offered, but also feels comfortable while traveling and gets the image of the branding provided.
\end{abstract}

Keywords: Entrepreneurship, Empowerment, UKM, Tourism Culinary.

\section{PENDAHULUAN Analisis Situasi a. Profil Mitra}

Persaingan ekonomi global menjadi tantangan tersendiri bagi pelaku Usaha Kecil dan Mikro (UKM) bidang kuliner. Pengelolaan UKM kuliner saat ini masih belum terintegrasi dengan pengembangan kawasan wisata, khususnya terkait dengan kemandirian dan kewirausahaan generasi muda, peralatan produksi dan penyediaan area wisata kuliner untuk kenyamanan konsumen. Untuk itu perlu adanya pengembangan kawasan wisata yang terintegrasi dengan keberadaan pelaku UKM bidang kuliner dan memiliki potensi membangkitkan generasi muda untuk berwirausaha, sehingga dapat memberdayakan 
masyarakat dan meningkatkan kesejahteraan. UKM memiliki peluang untuk dikembangkan melalui pemanfaatan seluruh sumber daya yang dimiliki baik sumber daya manusia, sumber daya alam, serta kearifan budaya lokal, sehingga menjadi kekuatan ekonomi masyarakat setempat (Kurniawati, F., Mukzam, dan Djudi, M., 2017).

Dalam menghadapi persaingan yang semakin ketat, UKM produk kreatif harus siap bersaing dalam ekonomi global (Sasono, E. dan Rahmi, Y, 2014). Untuk itu perlu adanya pengembangan produk kreatif UKM yang memiliki nilai ekonomi dan daya saing tinggi serta mampu menyerap tenaga kerja, sehingga dapat menekan angka pengangguran dan kemiskinan.

Perwilayahan destinasi kota Malang sudah tidak dapat digali lagi sehubungan dengan padatnya bangunan yang ada di kota Malang seperti pemukiman dan perkantoran. Sehingga dalam pengembangan wisata kota lebih menekankan kepada peningkatan kualitas daya tarik wisata yang ada yaitu penyelenggaraan wisata kuliner, pendidikan, religi dan kegiatankegiatan MICE, yakni Meetings, Incentives, Conventions dan Exhibitions sektor pariwisata (Setioko, M.D., 2019).

Keragaman jenis makanan tradisional sebagai salah satu kekayaan budaya harus dilestarikan, sedangkan makanan modern sebagai dampak pasar bebas dan globalisasi harus dikembangkan kualitas serta pemasarannya. Melalui kreativitas pengembangan wisata kuliner diharapkan dapat meningkatkan semangat kemandirian dan jiwa berwirausaha bagi generasi muda di masa mendatang.

Agar memudahkan pencapaian keberhasilan Program Unmer Membangun Desa, maka pelaksanaannya difokuskan kepada sasaran yang mempunyai dampak besar terhadap peningkatan kesejahteraan masyarakat. Salah satu wilayah di Kota Malang yang sebagian warganya adalah generasi muda yang berwirausaha di bidang kuliner adalah di Kelurahan Bunulrejo Kecamatan Blimbing khususnya di RT.02 / RW.13. Wilayah ini sangat potensial namun belum dikembangkan menjadi kawasan wisata.

Para pelaku UKM bidang kuliner yang ada di wilayah ini membentuk wadah untuk beraktifitas bersama dengan nama "Kampung Kuliner Pring Koening". Komunitas ini dipilih sebagai mitra dalam Program Unmer Membangun Desa dengan fokus mengintegrasikan pengelolaan UKM kuliner dengan pengembangan kawasan wisata serta pembinaan kemandirian dan kewirausahan bagi generasi muda di wilayah tersebut.

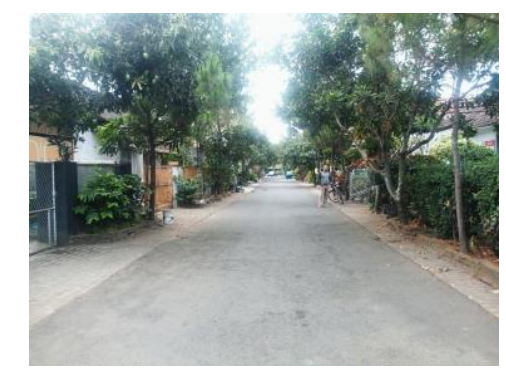

(Sumber : Dokumentasi Tim Pengabdi)

Gambar 1. Area Kampung Kuliner Kelurahan Bunulrejo

Diskusi awal dilakukan antara Tim Pelaksana program ini dengan Mitra UKM untuk mengidentifikasi permasalahan yang dihadapi beserta skala prioritasnya, sehingga diputuskan untuk membantu komunitas UKM di wilayah ini dalam hal peralatan produksi, pembinaan kewirausahaan dan pengembangan kawasan wisata. Beberapa produk makanan / minuman (kuliner) yang dihasilkan oleh UKM di wilayah ini adalah warung kopi, pisang coklat, martabak, terang bulan, pizza nagoya, sembako, roemah mie, nasi pecel, pizza 
delivery, risol mayo, rice bowl, soto ayam, burger mini, tempura, aneka minuman dan oleholeh khas Malang.

\section{b. Aspek Produksi dan Manajemen Usaha Mitra}

Produksi makanan / minuman dari UKM yang ada di wilayah ini masih dilakukan sendiri di rumah masing-masing. Memakai peralatan yang sederhana dan belum menggunakan booth yang terintegrasi dalam satu kampung. Jenis makanan / minuman yang diproduksi sudah beraneka ragam namun masih belum tertata rapi dari segi penyajian dan tata letak (layout) nya.

Manajemen dijalankan secara sederhana, yakni dengan melibatkan anggota keluarga. Pengelolaan keuangan masih manual dan belum dipisahkan antara keuangan untuk usaha dengan keuangan rumah tangga. Pengetahuan manajemen juga masih kurang, sehingga keterampilan dalam hal sistem administrasi juga rendah. Namun wilayah ini sangat potensial untuk dikembangkan karena warganya memiliki semangat luar biasa untuk maju.

Pemasaran produknya masih dilakukan secara konvensional, dimana konsumen datang ke rumah warga untuk membeli produk yang diinginkan. Sekalipun pelanggan setianya cukup banyak, namun mereka datang hanya untuk membeli produknya dan langsung kembali pulang. Di sinilah perlunya diintegrasikan dengan pengembangan kawasan wisatanya, sehingga konsumen bisa merasa lebih nyaman menikmati sajian kuliner, sekalian wisata dan ber-swa foto (selfie).

\section{Permasalahan Mitra}

Berdasarkan diskusi awal antara Tim Pelaksana program ini dengan mitra UKM diperoleh informasi bahwa permasalahan yang masih terjadi sampai dengan saat ini adalah belum terintegrasinya pengelolaan UKM kuliner dengan pengembangan kawasan wisata, khususnya terkait dengan kemandirian dan kewirausahaan generasi muda, peralatan produksi dan penyediaan area wisata kuliner untuk kenyamanan konsumen.

Secara spesifik permasalahan tersebut dapat dituliskan sebagai berikut :

a. Penyajian produk masih terpisah di rumah masing-masing UKM.

b. Belum memiliki booth yang dapat digunakan untuk meletakkan produk dan membranding kampung wisata kuliner.

c. Pemahaman warga pelaku UKM yang masih rendah tentang Mindset Entrepreneur, Sistem Administrasi Bisnis dan Manajemen Pengelolaan Kawasan Wisata.

\section{Alternatif Solusi}

Alternatif solusi yang digunakan untuk menyelesaikan permasalahan mitra di atas adalah membuat booth dengan desain yang dapat digunakan untuk mem-branding Kampung Wisata Kuliner Pring Koening. Booth ini menjadi sarana untuk meletakkan produk dan bisa ditata berjajar di sepanjang area kuliner di wilayah ini.

Untuk memberikan pemahaman kepada warga pelaku UKM di wilayah ini dilakukan pendampingan / pelatihan oleh tim pengabdi dengan materi : Mindset Entrepreneur, Sistem Administrasi Bisnis dan Manajemen Pengelolaan Kawasan Wisata. Materi ini juga sesuai dengan latar belakang keilmuan tim pengabdi.

\section{METODE PELAKSANAAN}

Metode pelaksanaan Program Unmer Membangun Desa ini dijabarkan dalam bentuk tahapan atau langkah solusi atas dasar permasalahan yang dihadapi mitra, yakni Tahap Observasi, Tahap Konsolidasi serta Tahap Monitoring dan Evaluasi. 


\section{Tahap Observasi}

Tahap ini diawali dengan survei ke lokasi mitra, brainstorming dengan pelaku UKM kuliner serta menggali potensi dan permasalahan yang terjadi di wilayah ini.

Permasalahan dalam aspek produksi dan mindset entrepreneur teridentifikasi karena peralatan produksi yang dimiliki UKM masih sederhana, penyajian produk masih terpisah di rumah masing-masing pelaku UKM, belum memiliki booth yang dapat digunakan untuk meletakkan produk dan mem-branding kampung wisata kuliner, serta pemahaman warga pelaku UKM yang masih rendah tentang Mindset Entrepreneur, Sistem Administrasi Bisnis dan Manajemen Pengelolaan Kawasan Wisata.

Aktifitas Program Unmer Membangun Desa ini merupakan kelanjutan dari kegiatan penelitian dan pengabdian tim terdahulu, antara lain : Penelitian tentang Penerapan Metode Kansei Engineering Guna Mengidentifikasi Atribut Desain Dalam Perancangan Souvenir Khas Malang (2014-2015), Menumbuhkembangkan Wirausaha Mahasiswa dan Alumni Melalui Program Ipteks bagi Kewirausahaan di Universitas Merdeka Malang (2016), Pengabdian Pelatihan Desain Kemasan Produk untuk UKM Kerajinan, Kuliner dan Posdaya (2017), serta Pengabdian Model Pendampingan UKM Bidang Kerajinan Menjadi Start-Up Sukses di Kota Malang (2018).

\section{Tahap Konsolidasi}

Dalam pelaksanaan Program Unmer Membangun Desa ini, para pelaku UKM kuliner di wilayah ini turut aktif berpartisipasi dalam pengembangan kawasan wisata kuliner dan aktif mengikuti setiap pembinaan yang dilakukan oleh Tim Pelaksana Program.

Solusi yang ditawarkan akan berdampak positif karena branding yang dilakukan terhadap sarana kampung wisata kuliner dan berbagai aktifitasnya bisa menjadi image yang ditangkap oleh setiap konsumen yang datang di Kampung Wisata Kuliner Pring Koening ini. Sedangkan outcome yang diharapkan dari program ini adalah meningkatnya produktivitas dan omzet penjualan bagi UKM di wilayah ini.

\section{Tahap Monitoring dan Evaluasi}

Monitoring dan evaluasi pada aspek produksi dikerjakan dengan membandingkan produktivitas sebelum dan sesudah dilakukan penambahan peralatan produksi, yang diharapkan akan meningkatkan jumlah produksi dan omzet UKM per bulannya.

Evaluasi pada aspek pengembangan kawasan wisata dikerjakan dengan membandingkan banyaknya konsumen yang datang berkunjung, sebelum dan sesudah dilakukan pengembangan terhadap kawasan wisata kuliner ini.

\section{PELAKSANAAN KEGIATAN}

Kegiatan dalam program ini diawali dengan brainstorming bersama pelaku UKM kuliner di RT.02 / RW.13 Kelurahan Bunulrejo Kecamatan Blimbing Kota Malang, menentukan dimensi booth atas dasar area penempatannya, pembuatan desain booth yang dapat memberikan branding kampung wisata kuliner dan penyerahan prototype booth kepada UKM mitra sebagai wujud nyata dari produk yang dirancang.

Pendampingan kepada UKM mitra dilakukan melalui kegiatan pelatihan Mindset Entrepreneur, Sistem Administrasi Bisnis dan Manajemen Pengelolaan Kawasan Wisata yang dilaksanakan secara daring. Kemudian dilanjutkan dengan mempresentasikan desain booth yang dihasilkan dalam Seminar Nasional Teknologi SISTEK 2020. Program ini diakhiri dengan Focus Group Discussion (FGD) untuk mengevaluasi pelaksanaan program secara menyeluruh. 


\section{Brainstorming dengan Pelaku UKM}

Brainstorming bersama pelaku UKM kuliner di RT.02 / RW.13 Kelurahan Bunulrejo Kecamatan Blimbing Kota Malang dilakukan untuk mengidentifikasi permasalahan yang dihadapi beserta skala prioritasnya, yakni membantu komunitas UKM di wilayah ini dalam hal peralatan produksi (desain booth), pembinaan kewirausahaan dan branding kawasan wisatanya.

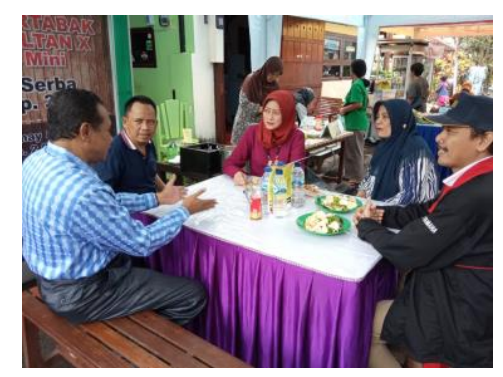

(Sumber : Dokumentasi Tim Pengabdi)

Gambar 2. Brainstorming dengan Pelaku UKM Kuliner

\section{Penentuan Dimensi Booth}

Dimensi booth ditentukan atas dasar area penempatan yang ada di lokasi kampung kuliner. Tinggi booth $175 \mathrm{~cm}$ terdiri atas tiga bagian (tempat meletakkan produk $75 \mathrm{~cm}$, penyangga rak peralatan $75 \mathrm{~cm}$ dan rak peralatan $25 \mathrm{~cm}$ ). Panjang booth $150 \mathrm{~cm}$, lebar booth $60 \mathrm{~cm}$, lebar penyangga rak peralatan $25 \mathrm{~cm}$, lebar tempat kompor $35 \mathrm{~cm}$. Untuk branding UKM (Panjang $150 \mathrm{~cm}$, Lebar $75 \mathrm{~cm}$ ), branding kampung wisata kuliner (Panjang $150 \mathrm{~cm}$, Lebar $25 \mathrm{~cm})$.

\section{Pembuatan Desain Booth}

Dari data dimensi yang ditentukan atas dasar area penempatannya, dibuat desain booth yang dapat merepresentasikan booth secara visual.

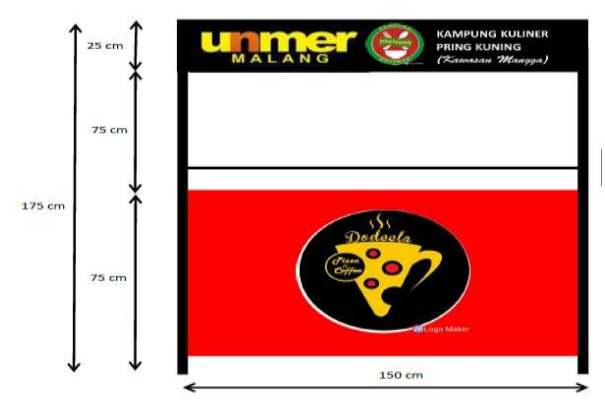

(Sumber : Pengolahan Data)

Gambar 3. Desain Booth Tampak Depan

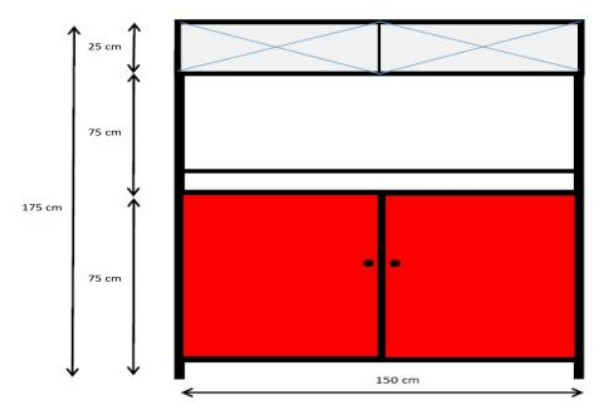

(Sumber : Pengolahan Data)

Gambar 4. Desain Booth Tampak Belakang 


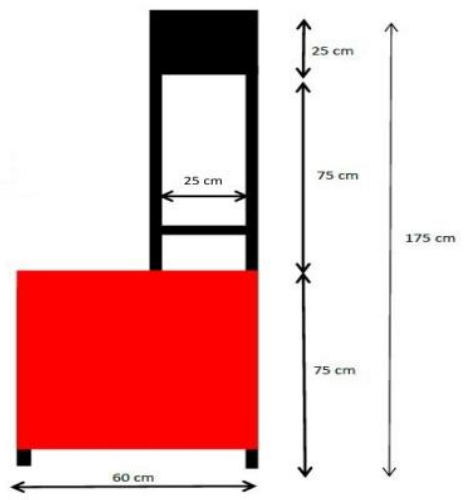

(Sumber : Pengolahan Data)

Gambar 5. Desain Booth Tampak Samping

\section{Pembuatan Prototype Booth}

Dari desain yang dihasilkan dibuat prototype booth sebagai wujud nyata dari produk yang dirancang, sehingga desain booth yang dibuat benar-benar dapat memberikan branding kampung wisata kuliner di wilayah ini.

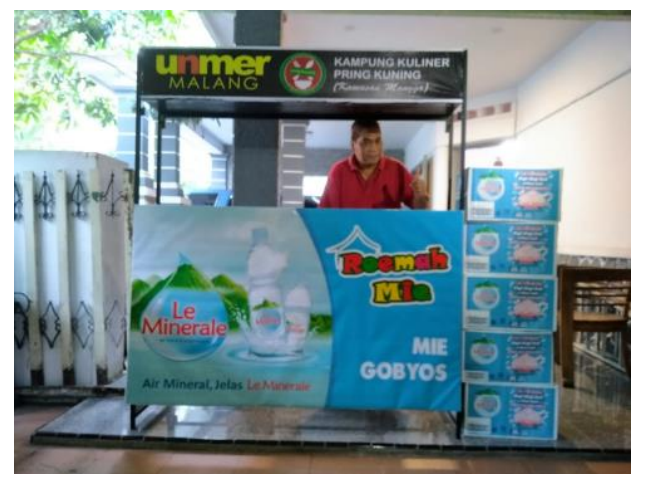

(Sumber : Dokumentasi Tim Pengabdi)

Gambar 6. Prototype Booth

\section{Penyerahan Booth ke Mitra}

Booth yang sudah selesai dibuat selanjutnya diserahkan ke mitra Paguyuban UKM Kampung Kuliner Pring Koening untuk dimanfaatkan para pelaku UKM di kampung ini dalam memasarkan produk kulinernya.
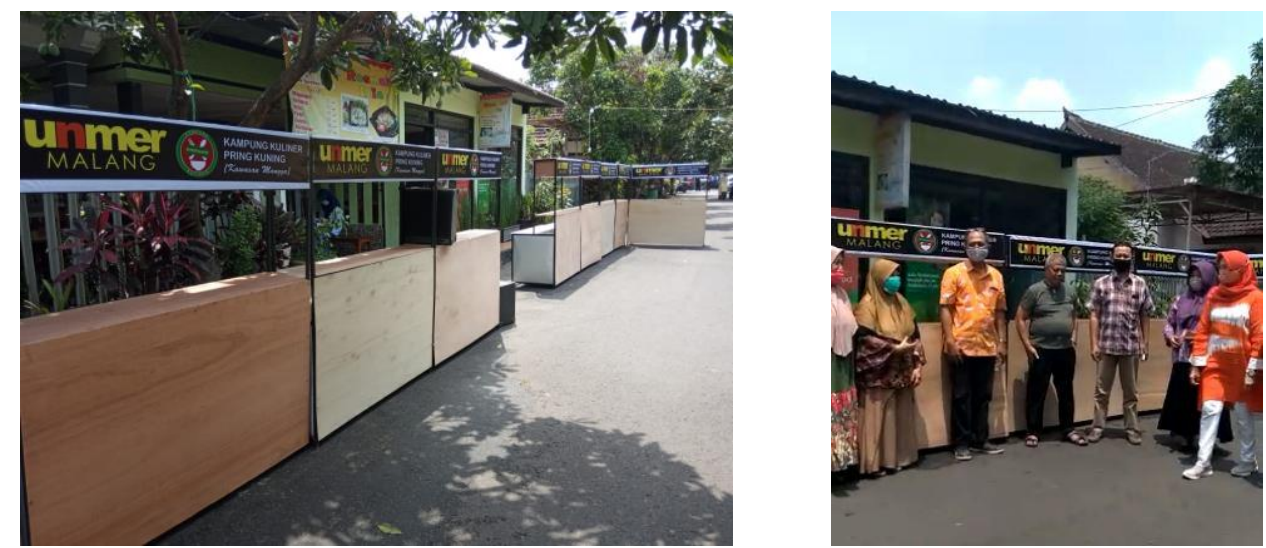

(Sumber : Dokumentasi Tim Pengabdi)

Gambar 7. Serah Terima Booth 


\section{Pendampingan Mitra}

Pendampingan kepada UKM mitra dilakukan melalui kegiatan pelatihan secara daring dengan materi :

1. Mindset Entrepreneur

Oleh : Dr. Mochammad Rofieq, S.Si., MT.

2. Sistem Administrasi Bisnis

Oleh : Dr. Roos Widjajani, M.Si.

3. Manajemen Pengelolaan Kawasan Wisata

Oleh : Dr. Nanny Roedjinandari, SST., Par., MM.

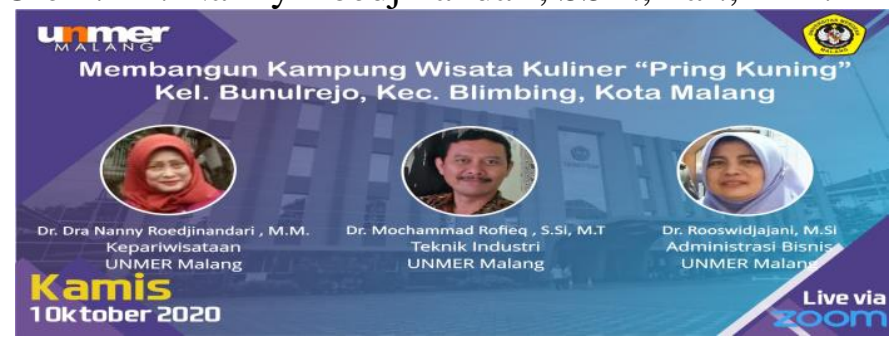

(Sumber : Dokumentasi Tim Pengabdi)

Gambar 8. Pelatihan Daring

\section{Seminar Nasional Teknologi SISTEK}

Diseminasi desain booth yang dihasilkan dari Program Unmer Membangun Desa ini dilakukan melalui presentasi dalam Seminar Nasional Teknologi SISTEK 2020.

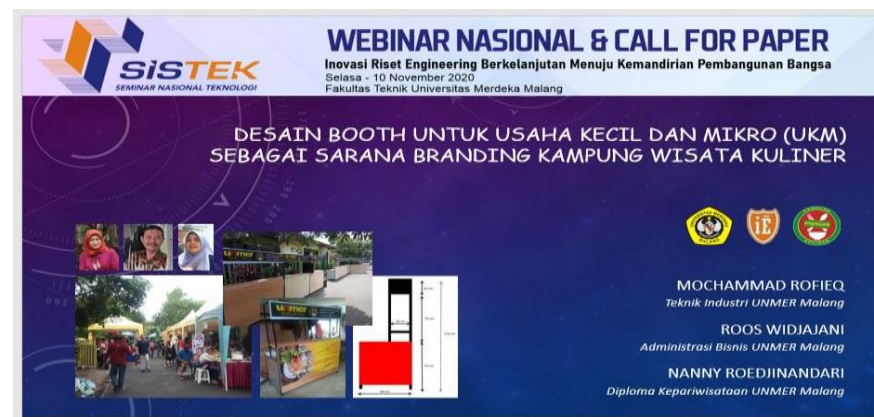

(Sumber : Panitia SISTEK 2020)

Gambar 9. Presentasi SISTEK

\section{Evaluasi Program Bersama Mitra}

Pelaksanaan Program Unmer Membangun Desa ini diakhiri dengan Focus Group Discussion (FGD) untuk mengevaluasi pelaksanaan kegiatan secara menyeluruh.

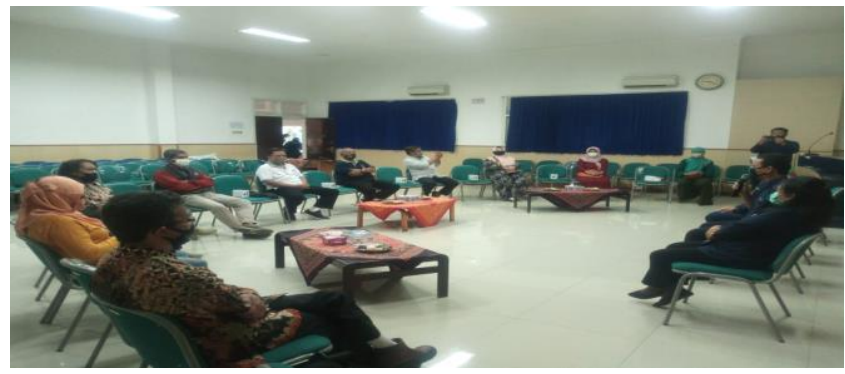

Gambar 10. FGD Evaluasi Program 


\section{KESIMPULAN}

Program Unmer Membangun Desa ini berdampak positif karena para pelaku UKM mendapatkan pendampingan dari akademisi dalam hal Mindset Entrepreneur, Sistem Administrasi Bisnis dan Manajemen Pengelolaan Kawasan Wisata. Selain itu booth yang dibuat dan diserahkan kepada UKM mitra beserta branding-nya akan menjadi image yang ditangkap oleh setiap konsumen yang datang berkunjung di Kampung Wisata Kuliner Pring Koening ini.

Outcome yang diharapkan dapat dicapai dari kegiatan ini adalah meningkatnya produktivitas dan omzet penjualan bagi UKM di wilayah ini. Evaluasi pengembangan kawasan wisata perlu dilakukan dengan membandingkan banyaknya konsumen yang datang, sebelum dan sesudah dilakukan branding terhadap kampung wisata kuliner ini.

Hal positif yang dapat disarankan kepada para pelaku UKM di wilayah ini agar keberlanjutan kampung wisata kuliner tetap terjaga adalah selalu menjaga kebersamaan dalam mengikuti berbagai aktifitas kuliner baik yang diadakan sendiri maupun yang diadakan oleh pihak lain seperti Kampus, Kelurahan, Kecamatan dan Pemerintah Kota Malang.

\section{DAFTAR PUSTAKA}

Budiyanto, H., dan Rofieq, M. "Menumbuhkembangkan Wirausaha Mahasiswa dan Alumni Melalui Program Ipteks bagi Kewirausahaan di Universitas Merdeka Malang”, Jurnal ABDIMAS Unmer Malang, Vol. 1 No. 1 (ISSN: 2548-7159), Des. 2016.

Kurniawati, F., Mukzam, dan Djudi, M. "Pelaksanaan dan Dampak Program Kemitraan dan Bina Lingkungan PT Pelabuhan Indonesia III (Persero) dalam Pengembangan UMKM (Studi Kasus pada Kampung Lawas Maspati Surabaya)", Jurnal Administrasi Bisnis (JAB) Universitas Brawijaya, Vol. 50 No. 2, Sept. 2017.

M. Rofieq, S. Hariyanto, dan N.M. Wiati, "Penerapan Metode Kansei Engineering Guna Mengidentifikasi Atribut Desain Dalam Perancangan Souvenir Khas Malang", dalam Simposium Nasional RAPI XIII FT UMS (ISSN: 1412-9612), 2014.

Rofieq, M., Poerwanto, A., dan Budiyanto, H. "Pelatihan Desain Kemasan Produk untuk UMKM Kerajinan, Kuliner dan Posdaya”, Jurnal ABDIMAS Unmer Malang, Vol. 2 No. 2 (ISSN: 2548-7159), Des. 2017.

Rofieq, M., Permatasari, D., dan Farida, L. "Model Pendampingan UMKM Bidang Kerajinan Menjadi Start-Up Sukses di Kota Malang", Jurnal ABDIMAS Unmer Malang, Vol. 3 No. 2 (ISSN: 2548-7159), Des. 2018. Sasono, E. dan Rahmi, Y. "Manajemen Inovasi pada Usaha Kecil Menengah", Jurnal STIE Semarang, Vol. 6 No. 3 (ISSN : 2252-7826), Hal. 74-90, Okt. 2014.

Setioko, M.D. "Analisis Strategi Pengembangan Wisata Kota di Kota Malang”, Jurnal Pariwisata PESONA, Vol. 04 No. 1 (ISSN: 2541-5859), Hal. 81-88, Juni 2019. 